[2] Shanthini Kasturi, Lisa R Sammaritano. Corticosteroids in Lupus. Rheum Dis Clin North Am, 42 (1), 47-62, viii

[3] César Magro-Checa, Juan Salvatierra, José Luis Rosales-Alexander, et al. Cardiovascular risk in systemic lupus erythematosus: implicated factors and assessment methods. Semin Fund Esp Reumatol. 2012;13(3):95-102

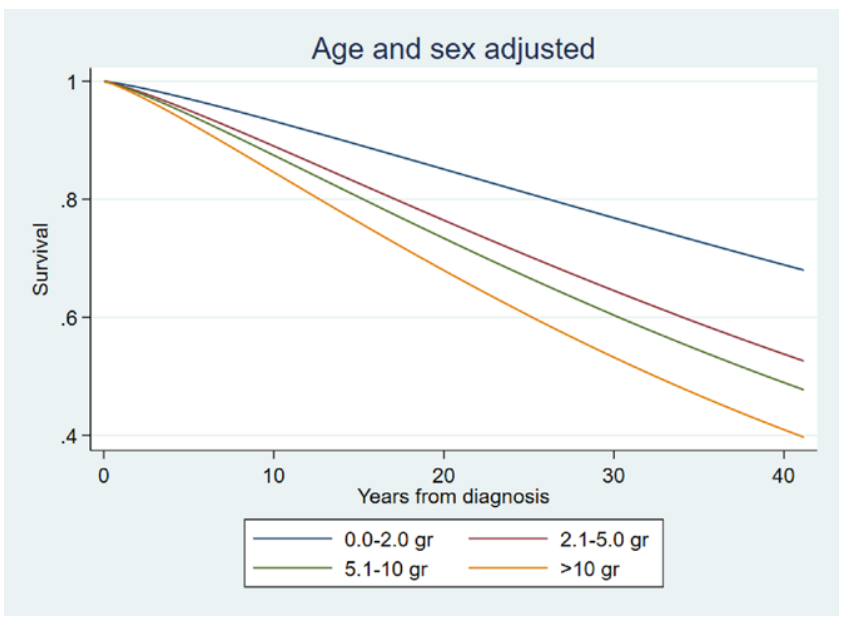

Disclosure of Interests: Sebastian Herrera Speakers bureau: academic conference, Juan camilo Diaz-Coronado: None declared, Diego Rojas-Gualdrón: None declared, Laura Betancur-Vasquez: None declared, Daniel Gonzalez-Hurtado: None declared, Juanita Gonzalez-Arango: None declared, laura Uribe-Arango: None declared, Maria Fernanda Saavedra Chacón: None declared, Jorge Lacouture-Fierro: None declared, Santiago Monsalve: None declared, Sebastian Guerra-Zarama: None declared, Juan david Serna: None declared, Julian Barbosa: None declared, Deicy Hernandez-Parra: None declared, Ana Sierra: None declared, Ricardo Pineda.Tamayo: None declared DOI: 10.1136/annrheumdis-2020-eular.6421

\section{AB0247 LIFE QUALITY AND DEPRESSION LEVEL ASSESSMENT IN PATIENTS WITH RHEUMATOID ARTHRITIS}

$\underline{T}_{\text {. Janković }}^{1,2}$, J. Zvekic-Svorcan ${ }^{2}$, B. Milić ${ }^{3}$, D. Vukliš ${ }^{4}$, R. Krasnik ${ }^{5}$ S. Subin ${ }^{6}$ on behalf of not. ${ }^{1}$ Faculty of Medicine, University of Novi Sad, Special Hospital for Rheumatic Diseases, Rheumatology, Novi Sad, Vojvodina, Novi Sad, Serbia; ${ }^{2}$ Faculty of Medicine, University of Novi Sad, Special Hospital for Rheumatic Diseases, Rheumatology, Novi Sad, Novi Sad, Serbia; ${ }^{3}$ Faculty of Medicine, University of Novi Sad, Nephrology and Clinical Immunology, Clinical Center of Vojvodina, Novi Sad, Serbia; ${ }^{4}$ Faculty of Medicine, University of Novi Sad, Novi Sad, Serbia; ${ }^{5}$ Faculty of Medicine, University of Novi Sad, Institute of Child and Youth Health Care of Vojvodina, Novi Sad, Serbia; ' General Hospital " DrDjordjeJoanović, Rheumatology, Zrenjanin, Vojvodina, Zrenjanin, Serbia

Background: Depression is a common and significant rheumatoid arthritis (RA) comorbidity that develops under the influence of severalfactors, the most important being disease activity, pain intensity and degree of disability.

Objectives: The goal of the investigation was to determine existence of depression and assess life quality in patients living with RA.

Methods: The study sample comprised of 150 patients of average age 59.2 years, $79.2 \%$ of whom were women and $20.8 \%$ were men, who have lived with RA for an average of 9.6 years. For determining disease activity level, Disease Activity ScoreDAS28was utilized. Pain intensity and global disease activity were rated using a visual analogue scale ranging from 1 to $100 \mathrm{~mm}$. For functional capacity assessments, Health Assessment Questionnaire(HAQ) index was adopted,depressions severity was determined through Back Depression Inventory (BDI), and Serbian version of the health-related quality of life instrument EQ-5Dwas employed to assess patients' quality of life.

Results: Average DAS28 score for the sample was4.46 \pm 1.32 , suggesting moderate RA activity. Pain intensity was on average scored at $53.2 \pm 18.6$, whereas global disease activity was measured at $49.63 \pm 20.2$, and theHAQ indexof $1.0 \pm 0.70$ was obtained. According to theBDI, $21.4 \%$ of the patients exhibited no signs of depression, whereas $12.9 \%$ had mild, $54.3 \%$ moderate, and $11.4 \%$ severe form of depression. Quality of life, as measured by EQ-5D, was compromised in all life domains, withpain/discomfort, anxiety/depression, inability to partake in usual activities, compromised mobility and self-caremost frequently reported. In patients suffering from moderate and severe depression, high statistically significant positive correlation between depression score and $\mathrm{HAQ}$ index was noted.BDIscore was statistically significantly positively correlatedwith the ratings on the EQ-5D scales pertaining to self-care, usual activities, pain/discomfort, and anxiety/depression.

Conclusion: Depression symptoms are common in patients with RA and can compromise quality of life in all life domains.When assessing disease severity and general status of patients with RA, depression symptoms should also be considered, given their high prevalence and influence on patients' everyday life.

Acknowledgments: not

Disclosure of Interests: None declared

DOI: 10.1136/annrheumdis-2020-eular.2957

\section{AB0248 PREVALENCE OF THYROID PEROXIDASE ANTIBODIES IN THE NORMAL POPULATION AND IN PATIENTS WITH RHEUMATOID ARTHRITIS AND THEIR PREDICTIVE VALUE FOR THE EFFECTIVENESS OF TREATING RHEUMATOID ARTHRITIS}

M. Kedves ${ }^{1}$, J. Csitos ${ }^{2}$, K. Törőcsik², A. Rideg ${ }^{2}$, I. G. Makkos ${ }^{2}$, D. Balaton ${ }^{2}$, A. Ozsvár ${ }^{2}$, L. Farkas ${ }^{2}$, J. Gál' ${ }^{1}{ }^{1}$ Bács-Kiskun County Hospital, Rheumatology, Kecskemét, Hungary; ${ }^{2}$ Bács-Kiskun County Hospital, Rheumatology, Kecskemét, Hungary

Background: Rheumatoid arthritis (RA) is sometimes associated with autoimmune thyroid disease (AITD) ${ }^{1}$. However the relation between RA autoantibodies and thyroid autoantibodies is doubtful. However, there is no reliable data on whether concomitant positivity of level of anti-TPO in rheumatoid arthritis patients alters the efficacy of RA therapy.

Objectives: To study the presence of level of autoimmune thyroid markers (thy roid peroxidase antibodies -anti-TPO-), in clinically and serologically differen forms of RA, compared to serum level of anti-TPO in control population, and to study whether anti-TPO positivity in any RA group influences the risk of high disease activity and also affects the likelihood of achieving DAS-28 remission. Methods: 1428 patients were included in the retrospective single-center study using the database of the Arthritis Registry of Kecskemét (ARK). 772 RA patients, subclassified according to the presence of RF and anti-MCV into seropositive RA patients (positive to one or both seromarkers), and seronegative RA (negative to both seromarkers), and 656 patients were included as control group without autoimmune diseases.

Results: Elevated level of anti-TPO was found in 199/772 (26\%) RA patients compared to controls 32\% (209/656). Furthermore, the level of anti-TPO was similar in seropositive and seronegative groups (24\% and $27 \%$ respectively). RA patients treated with biological therapy presented higher level of anti-TPO in $28 \%$, similarly to RA patients without biological therapy $(24 \%)$. There was no relevant difference in level of anti-TPO among the groups with different disease activity (high activity: DAS28 $>5.1 ;-24 \%$; moderate activity: DAS28 $\leq 5.1$; $>3.2$; - $25 \%$; and in low activity DAS28 $\leq 3.2$; - $28 \%$ respectively)

Conclusion: Our present data show that the elevated level of anti-TPO is similarly in patients with serologically different forms of RA and in the control group. The presence of anti-TPO antibody does not affect the severity of RA and the results obtained with the treatment, including that anti-TPO positivity does not increase the need for biological therapy.

\section{References:}

[1] Soliman E, Ghitany K, Bondok M, et al AB0343 Thyroid Autoantibodies in Seropositive Versus Seronegative Rheumatoid Arthritis: Is There a Link? Annals of the Rheumatic Diseases 2015;74:1008.

Disclosure of Interests: None declared

DOI: 10.1136/annrheumdis-2020-eular. 1580

\section{$\mathrm{AB} 0249$ \\ POSITIVE EFFECT OF ANTIRHEUMATIC THERAPY ON THE COURSE OF CHRONIC HEART FAILURE IN PATIENTS WITH EARLY RHEUMATOID ARTHRITIS}

I. Kirillova ${ }^{1}$, D. Novikova ${ }^{1}$, T. Popkova ${ }^{1}$, Y. Gorbunova ${ }^{1}$, E. Markelova ${ }^{1}$,

A. Volkov'. ${ }^{1}$ V.A. Nasonova Research Institute of Rheumatology, Moscow,

Russian Federation

\section{Background:}

Objectives: to evaluate the effect of antirheumatic therapy according to the "treat to target" strategy on the course of chronic heart failure (CHF) in patients with early RA.

Methods: The study included 22 patients $\mathrm{CHF}$ with valid diagnosis of RA (criteria ACR / EULAR, 2010), 17 (77\%) of women, median (Me) age - 60 years, Me disease duration - 7 months; IgM seropositive for rheumatoid factor $10(45 \%)$ and / or antibodies to the cyclic citrulline peptide 22 (100\%), DAS28-5.6 $[4,8 ; 6,5]$. CHF verified in accordance the recommendations for the diagnosis and treatment of $\mathrm{CHF}$ Society of Specialists in Heart Failure (2013). The concentration of NT-proBNP 